\title{
Evaluation of Accounting Systems Used by Companies in the Agriculture Sector in Jordan: A Field Study
}

\author{
Ziad M. Al-Saidat ${ }^{1}$ \\ ${ }^{1}$ Faculty of Business, Amman Arab University, Amman, Jordan \\ Correspondence: Ziad M. Al-Saidat, Department of accounting, Faculty of Business, Amman Arab University, \\ Amman, Jordan. E-Mail: saidat359_2150@yahoo.com
}

Received: November 1, 2013

Accepted: November 25, $2013 \quad$ Online Published: January 23, 2014

doi:10.5539/ijef.v6n2p87

URL: http://dx.doi.org/10.5539/ijef.v6n2p87

\begin{abstract}
This study aims at identifying the accounting systems applied in the agriculture sector in Jordan in order to evaluate and indicate the possibility of applying International Accounting Standard No. 41 (Agriculture) on this sector as well as the extent of the difference between the accounting systems used in the agriculture sector. To achieve this, a questionnaire has been developed to collect the necessary data from the sample of the study. The sample consists of fifty employees working in the financial sector at the agriculture sector. It has been shown from the analysis of the results that there is weakness in the accounting systems applied by the study sample companies.

In addition, the study shows that there is a difference between the accounting policies that are used in the agriculture sector and policies and items of the International Accounting Standard No. (41) for agriculture; the accounting systems used are traditional systems as the financial reporting is limited to the income statement and balance sheet, as shown by the similarity between the accounting systems used in the study sample companies.

Accordingly, the study recommends that there be a deep need to develop accounting systems applied in the agriculture sector through the creation of an appropriate environment to accept the application of accounting standards and amendments while starting the application gradually which will assure the success of the application process.
\end{abstract}

Keywords: accounting systems, agriculture, IAS 41, biology assets, plant assets

\section{Introduction}

The agricultural sector is one of the important sectors in the Jordanian economy; and a tributary of the Gross Domestic Product (GDP) The value of agricultural GDP for 2007 had come to (312.4) million dinars representing $(2.8 \%)$ of GDP, the livestock contributes of (55\%) thereof, the low contribution of this sector in GDP is attributed to the growth that has taken place in other sectors such as industry, services and real estate in addition to the high prices of production inputs; grazing lands are accounted for $90 \%$ of the area of the Kingdom; cultivated land has reached an area of (1.9) million acres distributed in field crops, vegetables and fruit trees; the size of the labor force in agriculture has reached (1.47) million workers. (Ministry of Agriculture Report, 2007).

In fact the importance of the agricultural sector can not be assessed through the ratio it form in the economy of the states but that importance comes from its role in providing food security when the prosperity of this sector is attained, thus enhancing the independence of decision-making.

Nowadays, the world is in the era of openness and free trade agreements, an era which requires the development of strategic plans that enable people to stay in situation of competition. We must recognize that trade agreements are unfair to the Third World countries, but the option of turning inward will not be less dangerous than opening up to the other without having the competitive ability, which means an inevitable globalization, therefore, if the agriculture sector, like any other sector, does not exceed the traditional methods of production in all its stages and become a strong competitor, it will erode bit by bit until it vanishes. Since decisions will be taken properly without the availability of appropriate information, the accounting as an information system is supposed to play an important role in supporting the decision-maker in the agriculture sector in a way no less important than the role of accounting in other sectors, especially the accounting systems in agricultural activities are no different than in any other economic facility, whether industrial, commercial, or service one. It is the measure of the cost, the services design, the planning and control, and the financial reporting on development of the agricultural facilities. 


\subsection{Importance of the Study and Objectives}

The importance of the study stems from the role of the agricultural sector as an effective component in the stability of economies and welfare of people. Under the presence of the International free trade agreements that allow the importation from other countries without fees or custom restrictions; and the failure of developing countries to protect their products and leaving them as an easy prey to compete with the same products of the strong economies, the situation needs the advancement of the financial reporting on the status of the agricultural sector in Jordan to support the decision-makers.

This study aims at:

- Introducing the accounting systems applied in the agriculture sector of Jordan and evaluating them. That is done through a statistical analysis of the study sample answers on the questionnaire' paragraphs which are related to the exploration of which accounting systems are used.

- Examining the viability of the financial environment for of the agriculture sector for the application of International Accounting Standard No. (41) which will be done by identifying the policies, laws and accounting regulations that apply in this sector and compare them with the requirements as stipulated in the standard of agriculture.

- Showing the difference between the accounting systems applied by companies in the agriculture sector of Jordan for which a comparison will be made the applied accounting regulations in agricultural companies and extracting the differences between these systems in order to reach a level of statistical differences and significance.

\subsection{Motives and the Problem of the Study}

The problem of the study is that the researcher believes that the development which has taken place recently in the accounting thought in relation to agriculture is not applied in Jordan, which means that the information resulting from the financial reporting does not make any support for the decision maker in the agricultural sector of Jordan. The study problem is summed up in trying to answer the following questions:

- What is the quality of accounting systems applied in the agriculture sector of Jordan?

- Is there any difference between the accounting systems applied by the different companies operating in the agricultural sector of Jordan?

- Is there any difference between the accounting policies followed by the companies operating in the agricultural sector of Jordan and policies contained in International Accounting Standard (41)?

\subsection{Hypotheses of the Study}

To answer the questions in problem of the study, we need to formulate the following hypotheses:

H01: there is no statistically significant difference between the accounting systems used in the agricultural sector of Jordan and good accounting systems.

H02: there is no statistically significant difference between the financial policies applied in the agricultural sector of Jordan and policies contained in International Accounting Standard No. (41).

H03: there is no statistically significant difference between the accounting systems applied in companies working in the agricultural sector of Jordan.

H04: there is no statistically significant difference between the accounting systems applied in the agricultural companies working in the plant activity and companies working in the animal activity.

\subsection{Definitions of Terms Used}

Agricultural activity: Project management for the biological transformation of biological assets intended for sale to agricultural production or other biological assets.

Biological transformation: Growth and loss of production, and reproduction operations, which cause quantity or quality changes in biological assets.

Agricultural production: Production gained from biological assets of the facility.

Biological asset: it is an animal or an a live plant.

Harvest: The separation of the crop from the biological origin or the cease of the dynamic process of biological origin.

Fair value: The value / exact amount of a commodity or asset in an active market by the seller and buyer mutually informed and willing to sell and purchase. 
Realizable value: This is a market value minus the cost necessary to complete the sale.

\subsection{Literature Review}

The agricultural sector is one of the first economic sectors known to mankind; and adopted by nations since ancient times as the output of agriculture from the plant activity and animal production are directly linked to human life as it is a source of food, a means of living. Henceforth, came the perception of farming communities as a process of backwardness in comparison with other societies. In spite of the rapid development in the technical side of agriculture in terms of seeds and fertilizers improvement and interest in the development of tools and equipment used in agriculture, the theoretical side in Accounting Agriculture has not received adequate attention by theorists accounting thought in different classifications, both academics or committees and councils arising from professional associations and institutes at least compared with other sectors of the economy. This is due to the wide industrial and service sectors and their connection with the economy of countries interested in the development of accounting thought.

As accounting is the result of the needs and constantly changing according to the change in the environment in which they operate to keep pace with the requirements of decision makers, it has evolved with the development of industry and services and other sectors. However, the evolution was not the same level in the agriculture sector, but with the beginnings of the third millennium a relative concern began with the accountability of the agricultural sector where Accounting Standards Board issued the International Accounting Standard No. (41) for agriculture.

The International Accounting Standard No. (41) came to be consistent with the trends of modern accounting theorists in shifting to fair value accounting, as the historical cost accounting has become not providing the necessary information for decision makers; instead, misleading them and giving way to rig the financial statements (benzion \& Hadad: 2003). The standard of agriculture has pointed out that there is a need to assess the biological assets whether plant or animal at fair value Accounting has benefited from some of the agricultural sector accounting treatments set out in International Accounting Standards through direct application or from being guided by them.

Keeping track of how to use accounting treatments for items of agricultural activity, it is clear that there is an application of some of the international accounting standards, as appropriate. We believe that the stock of agricultural products is treated in accordance with IAS 2 (inventory), and dealing with grants when they are linked to the biological asset in accordance with International Accounting Standard No. (20) accounting for government grants and disclosure, by adding the value of the grant to the rights of shareholders or as income of the entity during one financial period or more.

It also discloses the items that affect the revenue or expense in case of a substantial rise in accordance with International Standard No. 1 (Presentation of Financial Statements). It deals with the net exchange differences arising from translation of financial statements, whether from foreign operations or transactions in accordance with International Accounting Standard No. (21), accounting for the impact of changes in exchange rates of foreign exchange.

As for the intangible assets related to agricultural activity, they are administered by the International Accounting Standard No. (38) on intangible assets. The International Standard No. 16 (property and equipment) is applied at biological assets related to agricultural land. The biological asset is separated from the land before the measurement process. The application of the International Standard No. (36) impairment of assets on the biological assets is taking into account; assets' decline and settlement are tested in accordance with this standard.

It is clear that the magnitude of the size and diversity of the agricultural sector require many accounting treatments. So, the allocation of a single standard can not cover all these treatments, a case requires taking advantage of many other accounting standards as described above.

Most previous studies have focused on the suitability of IAS (41) on Agriculture to apply in the agriculture sectors in many countries in which these studies have been conducted. Hamada and Greit (2000) present a study on accounting for biological assets related to agricultural activity which showed the need to display biological assets within the budget in total or in groups; it retains the way of presentation to the project itself, in accordance with International Accounting Standard No. (1). As for the agricultural land, they see that it should be accounted in accordance with International Accounting Standard No. (16) property, plant, and equipment.

Argiles \& Solf (2001) investigate the new opportunities for accounting farms in Europe. It has been shown that there is a mismatch between the accounting principles and what is applied. The study suggests the development of the accounting information environment for farms in order to facilitate the application of IAS No. (41).

Elad (2002) studies the fair value accounting in the agriculture sector in which he shows that the possibility of 
applying fair value accounting on the agricultural sectors in many countries of the world, but this requires some changes in legislation that may not agree with that. Shaheen (2005) investigates the development of measurement and disclosure of accounting for biological assets in the context of international standards aiming at identifying the accounting policies applied by Egyptian agriculture companies in the area of disclosure and measurement of biological assets and identifying the difficulties facing it, as well as the degree of agreement with the International Accounting Standard (41).

Among the results of his study is that the fair value model is suitable for the application of some of the stages of the life cycle of biological assets/plant activity, but not all, while it may be suitable for the application at all stages of the life of the biological assets/animal activity.

The study recommends the need to distinguish between the stages of the life cycle of biological assets in order to identify the most appropriate way to measure and not to rely completely on the fair value as reported by the International standard for agriculture.

Douiri (2007) investigates the problems of accounting measurement in the activity of agricultural production and the proposals addressed in the framework of modern International Financial Reporting Standards. The study aims at identifying the problems of accounting measurement in the agricultural sector and finding a proper accounting measurement. It recommends that an attention should be paid to the agricultural theoretical accounting. Perry (2007) presents a study which shows that the obligation to apply the Agriculture No. 41 on the activities of the agricultural sector has led to additional expenses. The study indicates that these additional expenses exceed the benefit coming from the application; thus, the need to review the items regulating these expenses.

Karakaya (2009) studies the application of agricultural accounting in Turkey aiming at following the development in agricultural accounting from 1927 until 2007 through a survey of the accounting records. The study shows that accounting agriculture was developed by the public sector, as it has large agricultural facilities compared with the possession of the private sector which is mostly family possession.

Abdel Maksoud (2010) presents an approach for biological assets accounting in the agriculture sector in the light of the International Accounting Standards.

Aiming to classify accounting problems related to biological assets in the Egyptian agriculture sector and to provide an entrance to a comprehensive accounting measurement and disclosure for these assets.

The study concludes that fair value accounting suits some stages of the life cycle of biological assets, whether plant or animal, which means that it is inappropriate to apply the fair value accounting at all stages, but it can be applied to the activity of animal more than to the activity of plant; in addition, there is a difficulty remaining in determining the change in fair value at each balance.

She has made several recommendations including the need to separate the similar groups of the biological assets, which can determine the appropriate accounting policies for each group, and work to address the accounting problems that are not tackled by the International Accounting Standard No. (41) such as the promise of fruit gardens, citrus fruits and the national products, animal activity, and the accounting treatment of the biological asset during its life cycle.

When dealing with the theoretical accounting of Agriculture, one must review the main paragraphs of IAS (41) and how this standard addresses the biological assets in terms of recognition, measurement and disclosure during the period of possession by purchase or self-production, growth, loss and reproduction, as well as the accounting treatment of the initial measurement of the agricultural production at harvest time. It has been indicated by (Marsh, et. al, 20i3) that there is a difference between the International Financial Reporting Standards (IFRS) and U.S. standards with regard to the recognition of assets and products, international standards are moving to towards the fair value, while the U.S. standards are more conservative in this respect.

\subsubsection{Biological Assets Measurement and Recognition}

The recognition of the biological asset is achieved when the conditions in its definition are met as stated in accounting thought, where the asset is recognized if it meets the conditions for recognition of any item of the financial statements and these conditions are:

- The adopted definition is applicable to it.

- To be measurable by the monetary unit of measurement.

- Relevance.

- Reliability. 
But the main characteristics that all must be combined (in) assets are:

-The ability of the enterprise to control the asset.

-The potential for economic benefits in the future.

-The ability to control the asset and the benefits has to be the resultant of actual events and processes that took place in the past, not hypothetical.

The recognition of biological assets that is described in accounting thought is not different from the conditions required for the recognition of other assets, where the Accounting Standard 41 is consistent with that, and stated the following conditions for the recognition of biological asset:

- To have control over the asset.

-The potential for future economic benefits from the enterprise.

-The measurability of the asset at fair or cost value in a reliable way.

As stated in the International Accounting Standard No. (41) that the biological asset should be measured at initial recognition of fair value minus the necessary expenses to complete the deal.

In the absence of an active market to determine the fair value of the asset, one of the following alternatives should be used (Hammad, 2002).

- The price of latest similar deal, taking into account that no significant change in economic conditions happened from the date of the transaction until the date of the budget.

- Market prices for similar assets with adjustments to reflect the differences.

- The constituent units of the asset, such as kilogram of meat or a bushel / scale of the grove.

- Net cash flows expected from the (biological) asset discounted at a rate of effective interest.

The international standard (41) has taken care of the need for reliability of the fair value of biological assets and emphasized the use of cost subtracted from it the accumulated depreciation and impairment, if any, in case of the lack of reliability of fair value.

And added a paragraph in (2004) which referred to the need to deal with any specific prices (that) appear at any time in the future to enhance the reliability of fair value, and to limit the cost necessary to complete the sale ruled out the standard cost for the transfer and delivery of the goods to the market.

The researcher suggests here that a point of criticism of the fair value is weakness of reliable as compared with the historical cost, but that does not mean absolutely not available, which concludes that the reliability required by the standard is the highest rate possible.

\subsubsection{Accounting Measurement Problems of the Biological Asset}

Three cases appear in the life of biological asset which require accounting treatments and was taken care of by the International Accounting Standard No. (41) as follows:

1- First case: self-possession of biological asset.

A- Plant asset which is owned through the process of agriculture and the value of the asset is measured by knowing the cost required to produce the asset and considering it its initial cost.

B- Animal Asset: It is owned through the breeding and the value of the asset is determined at the fair value of the asset at birth minus the estimated cost to complete the deal.

2- Second case: the following expenses of the initial recognition.

A- Plant asset: The accounting treatment of expenditure which follows the initial recognition of the asset differs according to the classification of the asset if it is noncurrent, the expenditures are considered operative but if it is current, the expenditures are added to the initial value of the asset.

B- Animal asset: The accounting treatments of the following expenditures are similar for the initial recognition of the animal asset to the treatments that have to do with the plant asset.

3- The third case: re-evaluation of the biological asset after the initial measurement: Assessment is usually made in the date of the balance sheet and has to begin with realizable value when the reliability needed for the measurement is available. And when it is not available, the measurement is carried out according to the cost minus the accumulated depreciation and impairment losses.

The outputs of the biological assets are estimated when harvested using a realizable value. 


\subsubsection{Disclosure of Biological Assets}

The International Accounting Standard (41) required the recognition of the profits/losses that happened during the period of initial recognition of the biological asset and the agricultural produce, and required providing a description of each of the biological assets in addition to a description of the methods used in estimating the fair value of those assets, and required disclosing the fair value of the agricultural produces which were harvested during that period, in addition to a statement that shows the government grants and the substantial decrease in the level of grants, if any.

\section{Method}

\subsection{The Study Population and Its Sample}

The study population is depicted in the companies working in agriculture sector in Jordan where 50 employees, working in finance, were selected from six of the companies working in the sector; the sample was selected randomly from the population of the study.

\subsection{Study Tools and Statistical Methods Used}

To be able to answer the questions of the study, a number of hypotheses have been estimated and subjected to the test to see the level of acceptance and refusal to enhance the answers of these questions, and the questionnaire has been used to as a means to collect the necessary data to test hypotheses, where Likert's scale was applied, five paragraphs and weights ranged from (1-5); the questionnaire included (20) paragraphs the whole of which represent a test of all the study hypotheses. It was distributed on 50 employees represents those who consented and working in agricultural accounting. Thirty six sheets were returned and 7 of them were excluded, and thus the analysis was conducted on the answers of 29 only.

In order to analyze the data collected from respondents, the statistical program SPSS was used, the descriptive statistics as well as inferential statistics, T test, one way ANOVA. Independent, samples Test

\subsection{Validity and Reliability of the Study Tool}

To test the validity of the study tool, it was given to a group of experts in accounting, measurement and evaluation at Jordanian universities where it was modified according to their comments, for the reliability of the paragraphs of the questionnaire, Cronbach's Alpha coefficient was used, where the ratio was 0.72 , which is statistically acceptable (Uma, 2003).

\section{Discussion and Empirical Results}

\subsection{Hypotheses Test and Data Analysis}

First, the quality of accounting systems applied in the agricultural sector in Jordan.

The first hypothesis stated that there were no significant statistical differences between the accounting systems used in the agricultural sector of Jordan and good accounting systems, and to test this hypothesis, the statistical analysis, $\mathrm{T}$, was performed for answers of paragraphs pertaining to this hypothesis. They are shown in Table (1).

Table 1. The results of testing the first hypothesis: T. test

\begin{tabular}{lllll}
\hline $\mathrm{T}$ & Df & Sig & Mean & St.De \\
\hline 16.167 & 28 & 0.000 & 3.81 & 0.27 \\
\hline
\end{tabular}

Table 2. The average and standard deviation for paragraphs' answers of the questionnaire pertaining to the first hypothesis

\begin{tabular}{lllccc}
\hline No & paragraphs & N & Mean & Std. Deviation & Std. Error Mean \\
\hline 1 & You do not have an independent finance unit & 29 & 3.82 & 0.71 & 0.131 \\
2 & $\begin{array}{l}\text { No financial statements are prepared at the end of the period } \\
\text { in your company }\end{array}$ & 29 & 3.79 & 0.77 & 0.143 \\
3 & $\quad \begin{array}{l}\text { You do not have an integrated accounting book set } \\
4\end{array}$ & 29 & 3.08 & 0.90 & 0.168 \\
$\quad \begin{array}{l}\text { There is no computer hardware and software for financial } \\
\text { work in your company }\end{array}$ & 29 & 4.06 & 0.65 & 0.120 \\
& You do not have an integrated financial system & 29 & 3.93 & 0.79 & 0.148 \\
\hline
\end{tabular}




\begin{tabular}{|c|c|c|c|c|c|}
\hline 6 & $\begin{array}{l}\text { Workers in the financial affairs do not have any kind of } \\
\text { professionalism }\end{array}$ & 29 & 3.72 & 0.79 & 0.148 \\
\hline 7 & $\begin{array}{l}\text { You do not have any written internal regulations for the } \\
\text { financial affairs regulation }\end{array}$ & 29 & 3.79 & 0.81 & 0.151 \\
\hline 8 & You have the desire to raise the financial staff efficiency & 29 & 3.82 & 0.75 & 0.132 \\
\hline 9 & You feel weak in your competitive ability & 29 & 3.10 & 1.14 & 0.144 \\
\hline 10 & $\begin{array}{l}\text { You have sufficient financial information for decision } \\
\text { making }\end{array}$ & 29 & 3.68 & 1.22 & 0.135 \\
\hline 11 & $\begin{array}{l}\text { You care to see the accounting systems applied in other } \\
\text { similar companies }\end{array}$ & 19 & 3.51 & 0.87 & 0.146 \\
\hline 12 & $\begin{array}{l}\text { You have the ability to afford the necessary maintenance for } \\
\text { the development of the financial system }\end{array}$ & 29 & 3.31 & 0.84 & 0.125 \\
\hline 13 & You have the desire to possess a good financial system & 29 & 3.7 & 0.67 & 0.133 \\
\hline
\end{tabular}

The above table shows that the value of $\mathrm{T}=16.167$, and the average of the answers of the paragraphs that test this hypothesis is (3.81), which means rejecting the null hypothesis in terms of sig $=.000$, emphasizing the existence of a difference between the accounting systems applied in companies operating in the agricultural sector of Jordan and shows the good accounting systems. Table 2 shows the averages of the answers of the paragraphs that tested this hypothesis, where it shows that the highest average reached (4.06) and it has to do with the fourth paragraph of the questionnaire, which states the lack of computer software and hardware for accounting, while the lowest average for the answers of the third paragraph, which states that there is no comprehensive book set for accounting work.

Second, the difference between the accounting policies used in the agricultural sector of Jordan and policies stated in International Accounting Standard No. 41.

The second hypothesis stated that there was no difference between the accounting policies applied in the agricultural sector of Jordan and policies stated in International Accounting Standard No. (41).

To test this hypothesis, T. Test was used. The results are shown in Tables 3 and 4.

Table 3. The results of testing the second hypothesis: T. test

\begin{tabular}{lllll}
\hline $\mathrm{T}$ & Df & Sig & Mean & St. De \\
\hline 13.588 & 28 & 0.000 & 3.89 & 0.353 \\
\hline
\end{tabular}

Table 4. The average and standard deviation for the answers of the questionnaire paragraphs pertaining to the second hypothesis

\begin{tabular}{llllcc}
\hline No & paragraphs & $\mathrm{N}$ & Mean & Std. Deviation & Std. Error Mean \\
\hline 14 & $\begin{array}{l}\text { In you company there is no initial recognition for the } \\
\text { biological assets at fair value minus the necessary costs for } \\
\text { the completion of the sales process }\end{array}$ & 3.52 & 0.78 & .14 \\
15 & $\begin{array}{l}\text { Biological assets are not re-evaluated at each balance sheet } \\
\text { date. }\end{array}$ & 29 & 4.03 & 0.9 & .16 \\
$16 \quad \begin{array}{l}\text { Transfer costs are not excluded from the costs necessary to } \\
\text { complete the sale }\end{array}$ & 29 & 4.06 & 0.70 & .13 \\
$17 \quad \begin{array}{l}\text { Self-arising assets are not recognized as dividends } \\
18 \quad\end{array} \quad 29$ & 3.96 & 0.73 & .13 \\
$\quad \begin{array}{l}\text { To measure the fair value of biological assets, reliability is } \\
\text { not a required condition }\end{array}$ & 29 & 3.89 & .90 & .16 \\
$19 \quad \begin{array}{l}\text { You cannot modify the legislation related to the financial } \\
\text { affairs }\end{array}$ & 29 & 3.58 & 1.01 & .18 \\
20 & $\begin{array}{l}\text { You compare your accounting system with the systems used } \\
\text { by other similar companies }\end{array}$ & 29 & 3.82 & .75 & .14 \\
\hline
\end{tabular}


Table 3 shows that the ratio of $\mathrm{T}$ is 13.58 and the average of the answers of all the paragraphs that measure different accounting policies used between IAS 41 and applied to the Jordanian companies operating in the agricultural sector reached to (3.89) and the standard deviation of 0.353 and thus we cannot accept the null hypothesis, which means to accept the alternative hypothesis in terms of $\mathrm{Sig}=.000$. Here, the emphasis is on the existence of a clear difference between the accounting policies set out in standard 41 and accounting policies used in the companies operating in the agricultural sector of Jordan, and by expanding knowledge of the causes of the differences we made averages of the answers for the paragraphs that tested this hypothesis are high where the lowest average was 3.52 and is related to the paragraph that states the non-recognition of the initial biological assets at fair value minus the cost necessary to the point of sale. On the other hand, we see that the higher average reached 4.06 and pertains to the paragraph that provides for the exclusion of the costs of the transfer of assets to the market for sale and of the costs that arise from the fair value of biological assets. The reason for the difference may be due to weakness accounting systems used in the agricultural companies emphasized in the first hypothesis compared to the development in the policies of the recognition, measurement and disclosure to be followed.

Third, the difference between the accounting policies between companies operating in the agricultural sector of Jordan.

Under the third hypothesis that there is no difference between the accounting systems applied in companies operating in the agricultural sector of Jordan. To test this hypothesis, the statistical analysis One Way Anova has been used.

Table 5. The results of testing the third hypothesis: one way ANOVA

\begin{tabular}{lllccc}
\hline & Sum of squares & df & Mean square & F & sig \\
\hline Between Groups & .249 & 5 & .050 & .747 & .596 \\
Within Groups & 1.530 & 23 & .067 & & \\
Total & 1.779 & 28 & & & \\
\hline
\end{tabular}

It's clear from Table 5 which analyzes variance on (ANOVA) that the variation between the groups has reached (0.249) within (5) degrees of freedom and has reached the value of $F(0.747)$ and the level of 0.596 which is not statistically significant at the significance level $(\mathrm{P}<0.05)$.

Based on the above, the null hypothesis is accepted that there are no statistically significant differences between the accounting systems applied at companies in the agricultural sector of Jordan.

It is clear from Table 7 which pertains to Scheffe test that the averages of the companies are close, ranged between (3.68-3.9), as seen from the results of the analyses between multiple companies that Sig is not statistically significant when comparisons are complete in the sense there is no difference in accounting systems between companies in case of binary comparison as shown in Table 6 .

Table 6. Results of multiple comparisons test / Scheffe

\begin{tabular}{lccc}
\hline com (1) & com $(\mathrm{J})$ & Mean Difference $(1-\mathrm{J})$ & sig \\
\hline 1 & 2 & 0.25 & 0.795 \\
& 3 & 0.24 & 0.854 \\
& 4 & 0.14 & 0.979 \\
& 5 & 0.26 & 0.767 \\
2 & 6 & 0.22 & 0.868 \\
& 1 & -0.25 & 0.795 \\
& 3 & -0.01 & 1.000 \\
& 4 & -0.11 & 0.993 \\
& 5 & 0.01 & 1.000 \\
3 & 6 & -0.03 & 1.000 \\
& 1 & -0.24 & 0.854 \\
& 2 & 0.01 & 1.000 \\
& 4 & -0.1 & 0.997 \\
& 5 & 0.02 & 1.000 \\
4 & 6 & -0.03 & 1.000 \\
& 1 & -0.14 & 0.979 \\
& 2 & 0.11 & 0.993 \\
\hline
\end{tabular}




\begin{tabular}{cccc}
\hline & 3 & 0.1 & 0.997 \\
& 5 & 0.12 & 0.989 \\
5 & 6 & 0.08 & 0.998 \\
& 1 & -0.26 & 0.767 \\
& 2 & -0.01 & 1.000 \\
6 & 3 & -0.02 & 1.000 \\
& 4 & -0.12 & 0.989 \\
& 6 & 0.04 & 1.000 \\
& 1 & -0.22 & 0.868 \\
& 2 & 0.03 & 1.000 \\
& 3 & 0.02 & 1.000 \\
& 4 & -0.08 & 0.998 \\
& 5 & 0.04 & 1.000 \\
\hline
\end{tabular}

Table 7. Scheffe test results

\begin{tabular}{llc}
\hline Com & N & Subset of alpha $=0.05$ \\
\hline 5 & 5 & 3.68 \\
2 & 5 & 3.69 \\
3 & 4 & 3.7 \\
6 & 5 & 3.72 \\
4 & 5 & 3.8 \\
1 & 5 & 3.94 \\
Sig & & .782 \\
\hline
\end{tabular}

Fourth, the difference between the accounting systems applied in the agricultural companies operating in the plant activity and companies operating in the animal activity.

The hypothesis states there are no statistically significant differences between the accounting systems applied to companies operating in the agricultural activity and enterprises operating in the animal activity.

Table 8. The average and standard deviation for paragraphs answers that test the fourth hypothesis

\begin{tabular}{lllcc}
\hline Activity & $\mathrm{N}$ & Mean & Std.Deviation & Std.Error Mean \\
\hline Animal & 15 & 3.83 & 0.291 & 0.075 \\
Plant & 14 & 3.67 & 0.17 & 0.046 \\
\hline
\end{tabular}

Table 9. Independent-samples test

\begin{tabular}{lllllll}
\hline & $\mathrm{F}$ & $\mathrm{Sig}$ & $\mathrm{T}$ & $\mathrm{Sig}(2$-tailed $)$ & $\mathrm{df}$ & Mean difference \\
\hline Equal Variance Assumed & 5.89 & 0.022 & 1.838 & .077 & 27 & .165 \\
Equal Variance not Assumed & & & 1.869 & .074 & 23.116 & .165 \\
\hline
\end{tabular}

It appears from Table 8 which analyzes descriptive statistics that the average answers of employees in the activity of animal (3.83) and standard deviation (0.291) with average of (3.67) of the answers of employees in the activity of plant and the standard deviation of (0.17), as evidenced by Table 9 that $\mathrm{T}$ has reached (1.838) when the degrees of freedom (27) and the level of $\mathrm{Sig}=(0.077)$ which is not statistically significant at $\mathrm{P}<.05$, which means accepting the null hypothesis, which states there is no difference between the systems accounting principles applied in agricultural companies operating in the activity of plant and agricultural companies operating in the animal activity.

\section{Conclusion}

The statistical analysis of questionnaire paragraphs answers shows the following:

- The lack of modern accounting systems in companies operating in the agriculture sector in Jordan. This is due to 
the presence of weakness in competitive ability resulting from the lack of modern technology accounting treatments in addition to the lack of the existence of complete book sets which affects the decision-making processes.

- There is no difference between accounting systems applied in companies operating in the agricultural sector of Jordan. This might be attributed to the fact these agriculture companies are somehow similar in their financial abilities which do not provide the required financial resources to cover the cost of the modern financial systems.

- There is a difference between the accounting policies used in the companies operating in the agricultural sector of Jordan and policies contained in International Accounting Standard No. (41). The non-compliance with the requirements of the standard is a result of the lack of interest in legislation that governs the accounting work, especially the regulations in force are still primitive.

- There is no difference between the accounting systems applicable to companies operating in agricultural sector /animal activity and those working in the plant activity. The lack of difference between the two sectors (plant and animal) can be explained by the presence of a kind of weakness in the two financial systems applied in these two sectors.

After analyzing the results of the study and identifying the general level of accounting systems applied in the agricultural companies in Jordan, the researcher recommends:

- The need to focus on developing the professional capacity of workers in the finance sector in agriculture by including them in training sessions on accounting standards and how to apply it.

- The need to exchange expertise with financial companies that operate in the agricultural sector with the advanced countries in this area to learn how to calculate the costs to be used as a basis for competitive pricing.

- The necessity of starting the application of International Accounting Standard on Agriculture gradually.

\section{References}

Argiles, J. M., \& Solf, J. (2001). New opportunities for farm Accounting. European Accounting Review, 10(2), 361-383.

Asma, A. M. (2010). A proposed approach for accounting for biological assets in the agriculture sector in the light of the International Accounting Standards: An empirical study. Unpublished MA Thesis, University of Suez Canal, Egypt.

Benzion, \& Haddad. (2003). Fair value accounting and the management of the firm. Critical perspectives on Accounting ,14(4), 383-415. http://dx.doi.org/10.1016/S1045-2354(02)00139-9

Douiri, S. (2007). Accounting measurement problems in agricultural production and activity of the proposals addressed in the framework of modern International Financial Reporting Standards. The Scientific Journal of the Faculty of Commerce, 1.

Elad, C. (2002). Fair value accounting in the agriculture sector: Some implication for International accounting harmonization. European Accounting Review, 13(4), 621-641. http://dx.doi.org/10.1080/0963818042000216839

Hamada, R. A., \& Garit, E. A. (2000). Accounting for biological assets related to agricultural activity. Journal of Arab Chartered Accountant, 113(1).

Hammad, T. A. A. (2002). Encyclopedia of accounting standards. Part IV, Cairo.

International Accounting Standards Committee. (2001). International Accounting Standards (IAS), London .UK. Jordan, Ministry of Agriculture, Annual Report for 2007.

Karakaya, M. (2009). An overview to accounting applications on agricultural Activities in Turkey within historical progress. African Journal of Business Management, 3(7), 294-304.

Perry, R. (2007). Questions persist over new standard for agriculture. Chartered Accountants Journal of New Zealand Wellington, 68(3).

Sekaran, U. (2003). Research methods for business: A skill-building approach (4th ed.). Southern Illinois University at Carbondale, USA.

Shaheen, A. H. A. (2005). The development of measurement and disclosure of accounting for biological assets in the context of international accounting standards with the field study. Journal of the Faculty of Commerce for Scientific Research, 42. 
Treba, M., Stephen, F., \& Ficher, M. (2013). Accounting for agriculture products: US versus IFRS GAAP. Journal of Business \& Economics Research, 11(2), 79-87.

\section{Copyrights}

Copyright for this article is retained by the author(s), with first publication rights granted to the journal.

This is an open-access article distributed under the terms and conditions of the Creative Commons Attribution license (http://creativecommons.org/licenses/by/3.0/). 